Каменева B. A. Стратегия самопрезентации политика (на материале личного и официального блогов в Twitter вице-президента США Камалы Харрис) / В. А. Каменева, Н. В. Потапова // Научный диалог. — 2021. — № 11. - C. 82-105. — DOI: 10.24224/2227-1295-202111-82-105.

Kameneva, V. A., Potapova, N. V. (2021). Strategy of Self-Presentation of a Politician (Personal and Official Blogs on Twitter of US Vice President Kamala Harris). Nauchnyi dialog, 11: 82-105. DOI: 10.24224/2227-1295-2021-11-82-105. (In Russ.).

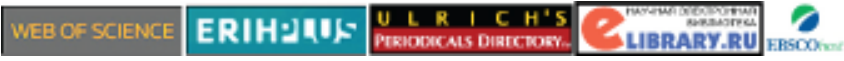

Журнал включен в Перечень ВАК

DOI: $10.24224 / 2227-1295-2021-11-82-105$

Стратегия самопрезентации политика (на материале личного и официального блогов в Twitter вице-президента США Камалы Харрис)

Каменева Вероника Александровна orcid.org/0000-0001-8146-9721 доктор филологических наук, профессор

кафедра романо-германской филологии Russia_science@mail.ru

Потапова Наталья Вадимовна orcid.org/0000-0001-7593-1713 кандидат филологических наук, доцент кафедра романо-германской филологии nv_potapowa@mail.ru

Кемеровский государственный университет (Кемерово, Россия)

Работа выполнена при финансовой поддержке фонда РФФИ, проект № 19012-00522 «Проблема легитимизации в политическом дискурсе: лингвоперсонологический аспект»

\section{Strategy of Self-Presentation of a Politician (Personal and Official Blogs on Twitter of US Vice President Kamala Harris)}

Veronika A. Kameneva

orcid.org/0000-0001-8146-9721

Doctor of Philology, Professor

Department of Romance and Germanic Philology

Russia_science@mail.ru

Natalia V. Potapova

orcid.org/0000-0001-7593-1713

$\mathrm{PhD}$ in Philology, Associate Professor

Department of Romance and Germanic Philology

nv_potapowa@mail.ru

\section{Kemerovo State University}

(Kemerovo, Russia)

This research was supported by the Russian Foundation for Basic Research, project No.19-012-00522 "The problem of legitimation in political discourse: linguistic and personological aspect"

(C) Каменева В. А., Потапова Н. В., 2021 


\section{ОРИГИНАЛЬНЫЕ СТАТЬИ}

\section{Аннотация:}

Рассматривается вопрос инвариантности тактик, репрезентирующих коммуникативную стратегию самопрезентации политика высшего эшелона власти США в личностно- и статусно-обусловленном дискурсе. Материал исследования составили 349 сообщений, извлеченных из личного блога Камалы Харрис в социальной сети Twitter в период с января по июль 2021 года, и 665 сообщений, отобранных из официального блога политика в указанный период. Актуальность подобных исследований объясняется необходимостью уточнения теоретико-методологических основ анализа политического интернет-дискурса с учетом статуса адресанта. Новизна настоящего исследования заключается в идентификации тактик, актуализирующих исследуемую стратегию на материале личностно- и статусно-обусловленного дискурса. Новизна работы также видится в том, что тактики самопрезентации политика изучены в сопоставительном аспекте. В результате исследования в личностно-обусловленном дискурсе были идентифицированы такие тактики, как солидаризация, призыв, иллюстрация достижений, благодарность, отождествление, гипертрофирование «я-темы». В статусно-обусловленном дискурсе авторами были зафиксированы тактики солидаризации, призыва, иллюстрации достижений, благодарности, отождествления, гипертрофирование «я-темы», обещания. Описаны языковые приемы, актуализирующие тактики самопрезентации в личностно- и статусно-обусловленном дискурсе.

\section{Ключевые слова:}

стратегия самопрезентации; самопрезентация политика; тактика; дискурс социальных сетей; политический интернет-дискурс.

\section{ORIGINAL ARTICLES}

Abstract:

The issue of invariance of tactics representing the communicative strategy of the politician of the highest echelon of US power in personality self-presentation and status-conditioned discourse is considered. The research material consisted of 349 posts extracted from Kamala Harris's personal blog on Twitter from January to July 2021 and 665 posts selected from the politician's official blog during this period. The relevance of such studies is explained by the need to clarify the theoretical and methodological foundations of the analysis of political Internet discourse, taking into account the status of the addressee. The novelty of this research lies in the identification of tactics that actualize the strategy under study on the basis of personality and status-based discourse. The novelty of the work is also due to the fact that the tactics of self-presentation of the politician are studied in a comparative aspect. As a result of the research in personality-conditioned discourse, such tactics as solidarity, appeal, illustration of achievements, gratitude, identification, hypertrophy of the "I-theme" were identified. In the status-conditioned discourse, the authors recorded the tactics of solidarity, appeal, illustration of achievements, gratitude, identification, exaggeration of the "I-theme", promises. The linguistic techniques that actualize the tactics of selfpresentation in personality and status-conditioned discourse are described.

\section{Key words:}

self-presentation strategy; self-presentation of a politician; tactics; social media discourse; political internet discourse. 


\section{Стратегия самопрезентации политика \\ (на материале личного и официального блога в Twitter вице-президента США Камалы Харрис)}

Саменева В. А., Потапова Н. В., 2021

\section{1. Введение}

Коммуникативные стратегии, используемые политиками в профессиональной коммуникации, длительное время находятся в центре исследовательского фокуса ученых разных стран. Отметим, что подавляющее количество работ выполнено на материале статусно-обусловленного политического дискурса разной жанровой направленности: информационных, призывных, убеждающих, оправдательных или покаянных текстов. Исследовательский интерес, как правило, заключается не только в установлении доминирующих стратегий политиков в статусно-обусловленном политическом дискурсе, но и в соотнесении их с такими аспектами коммуникативной ситуации, как общий контекст коммуникации, коммуникативная цель, адресат и др. [Беседина и др., 2019; Дайнеко, 2011; Дмитриева, 2018; Дубровская, 2017; Куралева и др., 2018; Моногарова и др., 2020; Мухортов, 2018; Паршина, 2005; Тымбай, 2018; Khajavi et al., 2020; Sadeghi, 2014]. Вне основного исследовательского интереса на сегодня остается вопрос об инвариантности или вариативности тактик, актуализирующих определенную коммуникативную стратегию политиков в личностно- и статусно-обусловленном дискурсе. Это позволяет говорить об актуальности и новизне настоящего исследования. Обращение к заявленной проблематике позволит внести определенный вклад в совершенствование не только методологии, но и теоретической базы сразу ряда лингвистических теорий и направлений: общей теории дискурса, теории коммуникации и политической лингвистики. Данная работа концептуально соотносится с теоретическими положениями политической лингвистики, общей теорией дискурса и теорией коммуникации [Горошко и др., 2019; Карасик, 2002; Милованова и др., 2020; Орлова, 2013; Устинова, 2018; Чудинов и др., 2018 и др.].

Основные термины настоящего исследования: коммуникативная стратегия, стратегия самопрезентации, тактика.

Широкое применение в лингвистике термина коммуникативная стратегия привело к появлению множества трактовок данного понятия. В настоящей работе вслед за Г. С. Филаткиной под коммуникативной стратегией понимается «план реализации заранее определенной цели 
коммуникативного поведения или взаимодействия политического субъекта, для достижения которой используется совокупность различных вербальных и невербальных тактик и приемов» [Филаткина, 2015, с. 14]. В политической области коммуникативная стратегия преследует три основные цели: проинформировать, изменить мнение, изменить поведение адресата. На сегодняшний день не существует общепринятой классификации коммуникативных стратегий, однако большинство исследователей выделяют следующие основные виды: самопрезентация, дискредитация, манипуляция и конвенция. В рамках данной статьи будет рассмотрена стратегия самопрезентации, ее речевые тактики и языковые приемы их актуализации.

Стратегия самопрезентации находится в поле зрения многих исследователей. Она рассматривалась на материале разных типов дискурса: политического [Филаткина, 2015; Ширяев, 2017 и др.], автобиографического [Волошина, 2014], военного [Уланов, 2014], судебного [Никифорова, 2012], женского диалектного [Демешкина и др., 2020], интернет-дискурса [Дайнеко, 2011] и др. Под стратегией самопрезентации понимают общую особенность социального поведения, способ управления впечатлением, самоподачу, представление желаемого образа аудитории, демонстрацию человеком своих личностных характеристик [Демешкина и др., 2020, с. 4748]. В задачи данной стратегии входит сообщить адресату некое знание, которое может преподноситься как обсуждение или рассуждение с целью защитить свою репутацию / сформировать положительный имидж и навредить репутации оппонента / разрушить его имидж.

Любая коммуникативная стратегия, в том числе и стратегия самопрезентации, реализуется посредством набора тактик. Тактика понимается как конкретный этап реализации коммуникативной стратегии, как совокупность приемов, направленных на решение определенной задачи. Коммуникативный прием при этом представляет собой способ воздействия на адресата, предполагающий использование вербальных и невербальных средств. Согласно Ю. Ю. Суханову, стратегия самопрезентации реализуется с помощью тактики оппозиционирования, тактики солидаризации, тактики отождествления [Суханов, 2018, с. 208]. О. Н. Паршина выделяет тактики солидаризации, отождествления (с кем-либо или чем-либо), создания «своего круга», дистанцирования (от политических конкурентов и тех, кто с ними ассоциируется), нейтрализации негативного представления о себе, гипертрофирования «я-темы», тактику акцентирования положительной информации и тактику эпатирования [Паршина, 2005]. Схожие тактики выделяет и В. А. Мишланов, добавляя тактику иллюстрации достижений [Мишланов и др., 2009, с. 11]. 
Гипотеза данного исследования состоит в том, что тактики, актуализирующие стратегию самопрезентации одного и того же политика, не будут варьироваться в личностно-обусловленном и статусно-обусловленном дискурсе. Предположительно, подобная инвариантность обусловлена тем, что в человеке, занимающем определенный пост в государстве, видят прежде всего политика, поэтому информация в его личных блогах трактуется как официальная позиция должностного лица. Это заставляет политика оправдывать подобные ожидания и даже в личностно-обусловленном дискурсе позиционировать себя в первую очередь как политика.

Для верификации гипотезы настоящего исследования был проведен комплексный анализ информации, размещенной на личной и официальной страницах Камалы Харрис - вице-президента США — в социальной сети Twitter. Обращение к личностно-обусловленному и статусно-обусловленному дискурсу данного политического деятеля представляет исследовательский интерес, так как К. Харрис нельзя назвать типичным представителем политической элиты США. Она имеет отношение сразу к нескольким социальным группам, получающим идеологически ангажированную дискурсивную репрезентацию по антропоцентрическим характеристикам, социальным ролям и социальному статусу. К. Харрис относится к женской гендерной группе, она замужем, она дочь иммигрантов, дочь этнической индианки и африканца, успешный юрист и политик.

Фактологическую базу исследования составили 349 сообщений, размещенных на личной странице политика в социальной сети Twitter [Kamala ...], и 665 сообщений, извлеченных из материалов, опубликованных на официальной странице К. Харрис [Vice President ...]. Отбор материала осуществлялся с применением приема сплошной выборки. В базу исследования включались все сообщения, появившиеся в рамках личностно-обусловленного и статусно-обусловленного дискурса, за полугодовой период - с января по июль 2021 года.

В ходе исследования привлекались как общенаучные методы, так и частнонаучные методы лингвистического анализа отобранного фактологического материала.

Методика анализа включала следующие процедуры: 1) отбор фактологического материала, относящегося к теме исследования; 2) выявление тактик, актуализирующих стратегию самопрезентации в личностно-обусловленном дискурсе К. Харрис в сети Twitter; 3) выявление тактик, актуализирующих стратегию самопрезентации в статусно-обусловленном дискурсе К. Харрис в сети Twitter; 4) описание языковых средств, актуализирующих исследуемые тактики в личностно-обусловленном дискурсе К. Харрис в сети Twitter; 5) описание языковых средств, актуализирующих 
исследуемые тактики в статусно-обусловленном дискурсе К. Харрис в сети Twitter; 6) сравнительный анализ тактик самопрезентации в личностно- и статусно-обусловленном дискурсе данного политического деятеля.

Проведенный анализ коммуникативной стратегии самопрезентации на материале личного и официального блогов политика позволил идентифицировать общие тактики солидаризации, призыва, иллюстрации достижений, благодарности, отождествления, гипертрофирования «я-темы». Исключением стала тактика обещания, которая была зафиксирована только в официальном блоге К. Харрис.

\section{2. Тактика солидаризации в личном и официальном блогах Камалы Харрис}

На личной странице в социальной сети Twitter вице-президент К. Харрис выражает солидарность с мнением Джо Байдена по ряду вопросов и поддерживает его призывы. Политик прибегает к данной тактике для демонстрации общности взглядов. К. Харрис дублирует сообщения президента США с его официальной страницы, преследуя аргументативную, конативную и эмоционально-оценочную цели. Ретвит, являясь повторной публикацией чужого или собственного твита, может квалифицироваться как цитата, принадлежащая по форме и объему к полным цитатам. Все дублируемые сообщения (ретвиты) можно разделить на тематические группы:

(1) Призывы президента США к вакцинации против COVID-19: We're closer than ever to declaring our independence from COVID-19, but the fight is not over yet. Powerful strains like the Delta variant have emerged. The best defense against these deadly variants is simple: get vaccinated [Kamala ...] (Мы как никогда близки к провозглашению независимости от COVID-19, но борьба еще не окончена. Появились мощные штаммы, такие как «Дельта». Лучшая защита от этих смертоносных вариантов - вакцинироваться).

(2) Высказывания Джо Байдена о равенстве, в частности о том, что власть имущие и богатые должны подчиняться законам, как и представители других социальных групп: Justice serves the people - it doesn 't protect the powerful [Ibid.] (Справедливость служит людям — она не защищает власть имущих).

(3) Высказывания президента о том, что надо бороться за достойную и безопасную жизнь чернокожих в США: A Black man should be able to go for a jog without fearing for his life [Ibid.] (Чернокожий мужчина должен быть в состоянии отправиться на пробежку, не опасаясь за свою жизнь).

(4) Поздравления с праздниками, в которых есть призыв к определенным действиям: After this long, hard year, America is back. We not only mark our independence as a nation, but we begin to mark our independence from this 
virus [Ibid.] (После этого долгого и тяжелого года Америка вернулась. Мы не только отмечаем свою национальную независимость, но и начинаем отмечать свою независимость от этого вируса).

В последнем случае, эксплицируя солидарность с позицией президента и правительства относительно принимаемых мер по борьбе с пандемией, К. Харрис дублирует поздравление Джо Байдена с Днем Независимости США, вселяя уверенность в граждан напоминанием о том, что народу, который одержал победу в борьбе за свои права и свободы, по силам выиграть и войну в борьбе с пандемией.

Отметим, что К. Харрис дублирует и сообщения со своей официальной страницы в Twitter, подчеркивая, что она придерживается определенных взглядов или имеет определенное мнение и как вице-президент страны, и как обычный человек. Так, политик дублирует сообщения с призывом к вакцинации и ношению масок, призывом бороться за права женщин, трансгендеров, представителей ЛГБТ сообщества, афроамериканцев, латиноамериканцев, американцев с азиатскими корнями и иммигрантов из Азии: Right now, Asian Americans and Asian immigrants in our country are facing an increase in hate and violence. @POTUS and I are committed to working with the community to ensure all Americans are protected and respected [Ibid.] (Прямо сейчас американцы азиатского происхождения и иммигранты из Азии в нашей стране сталкиваются с ростом ненависти и насилия. @ Президент и я стремимся сделать все, чтобы все американцы чувствовали защиту и уважение).

На официальной странице в социальной сети Twitter вице-президент также выражает солидарность с мнением президента Джо Байдена по разным вопросам: борьбы с пандемией, защиты прав трансгендеров, расового равенства, достойных условий жизни работающих американцев и др. Так, говоря о Дне памяти жертв Холокоста (27 января), политик подчеркивает свою готовность работать с президентом по предотвращению геноцида: President Biden and I will continue to stand up to hatred in all forms and do everything we can to prevent future genocide. This is a moral obligation, and one that will help us build a safer, more secure world [Vice President ...] (Мы с президентом Байденом продолжим противостоять ненависти во всех ее формах и сделаем все возможное, чтобы предотвратить геноцид в будущем. Это моральное обязательство, которое поможет нам построить более безопасный мир).

К. Харрис выражает солидарность также с мнением и действиями своих коллег: члена Верховного суда США Елены Каган в вопросах, связанных с законом об избирательных правах; членов Кабинета в вопросах изменения климата, предотвращения насилия с применением огнестрельного оружия и др. 
Анализ лексической репрезентации данной тактики в личном и официальном блогах позволил зафиксировать использование:

1) местоимений we и our в инклюзивном значении, манифестирующем единство руководства и жителей страны как индикатор единства нации, символ признания усилий каждого гражданина в улучшении благосостояния страны: We not only mark our independence as a nation, but we begin to mark our independence from this virus (Мы не только отмечаем нашу независимость как нация, но и начинаем отмечать нашу независимость от этого вируса). We are powerful (мы сильны);

2) лексем с семантикой объединения и солидарности: join (объединяться, присоединяться), together (вместе), the unity (союз);

3) выражения to express our nation's solidarity with them (выразить солидарность нашей нации с ними).

Тактика солидаризации позволяет политику репрезентировать себя и в личном, и в официальном блогах соратником президента, деятельным членом его администрации, активно участвующим в решении ряда актуальных вопросов, который радеет за здоровье американцев, борется за равенство и справедливость для всех категорий граждан.

\section{3. Тактика призыва в личном и официальном блогах Камалы Харрис}

Анализ показал, что данная тактика используется политиком как в личном, так и в официальном блогах. Отличие заключается в том, что в личностно-обусловленном дискурсе К. Харрис призывает к ношению масок и вакцинации, а в статусно-обусловленном дискурсе, помимо призывов к борьбе с пандемией, политик призывает американцев верить в свои силы, верить в страну и в то, что сообща они могут достичь очень многого.

Так, в сложное для страны время, обусловленное борьбой с пандемией, политик многократно призывает своих подписчиков незамедлительно вакцинироваться. The fight isn't over. Get vaccinated; Shots are free. Get vaccinated; The President and I urge you to get vaccinated [Vice President ...] (Бой еще не окончен. Сделайте прививку; Прививки бесплатные. Вакцинируйтесь; Мы с Президентом призываем вас сделать прививки).

Не только борьба с пандемией является темой призывов, но и недопустимое жестокое отношение к еврейскому народу. The surge in anti-Semitic attacks against the Jewish community in the U.S. and around the world is despicable - it must be called out, condemned, and stopped. As a country, we must stand united against hate of any kind [Ibid.] (Всплеск антисемитских нападок на еврейскую общину в США и во всем мире вызывает презрение. Подобное необходимо выявлять, порицать и останавливать. Как страна, мы должны единым фронтом противостоять ненависти любого рода). 
К. Харрис известна также как политик, активно обсуждающий вопросы экологии, изменения климата. No nation or region is immune to climate change. So as a global community, it is imperative that we act quickly and together to confront this crisis [Ibid.] (Ни одна страна или регион не застрахованы от изменения климата. Поэтому нам как мировому сообществу крайне важно действовать быстро и сообща, чтобы противостоять этому кризису). Призывая граждан страны к действиям, вице-президент подчеркивает необходимость совместных усилий: только объединившись, можно изменить жизнь к лучшему.

На лексическом уровне тактика призыва актуализирована использованием модального глагола долженствования must (it must be called out; we must stand united; we must believe in ourselves; we must support them; we must do more); лексем с семантикой 'борьба', 'необходимость', 'призывать', 'вместе' (fight, it is imperative, urge, together, united). На синтаксическом уровне зафиксированы случаи употребления побудительных предложений (Get vaccinated; Let's not stop there; stay safe).

Прибегая к тактике призыва, вице-президент рассчитывает на отклик в сердцах подписчиков, на определенные действия с их стороны. При этом политик дает понять, что улучшение качества жизни - всеобщая задача, стоящая перед всем американским народом, достичь желаемого результата можно только сообща. Она же в свою очередь готова активно работать, поддерживать граждан, выполнять данные обещания.

\section{4. Тактика иллюстрации достижений в личном и официальном блогах Камалы Харрис}

В личном блоге К. Харрис позиционирует себя успешным политиком, работающим в эффективной команде под предводительством Джо Байдена. Говоря о достижении нового правительства в решении экономических проблем, вице-президент прибегает к полной цитации, размещая сообщения с официальной страницы президента США. Репрезентация тактики иллюстрации достижений позволяет К. Харрис выразить косвенную похвалу и себе как соратнику президента, работающему на благо страны: 3 million jobs since we took office. Our economic plan is working [Kamala ...] (3 миллиона рабочих мест с тех пор, как мы вступили в должность. Наш экономический план работает).

С одной стороны, К. Харрис говорит об улучшении экономической ситуации в стране, подчеркивая достижения президента. С другой стороны, политик имплицитно хвалит и свою работу, прибегая к местоимению we в его инклюзивном значении: Thanks to @JoeBiden's leadership,we've gotten the pandemic under control and put our economy back on track [Ibid.] 
(Благодаря руководству Джо Байдена мы взяли пандемию под контроль и вернули нашу экономику в нужное русло).

Дублируя сообщения Джо Байдена об успехах по обеспечению американцев доступной медициной, К. Харрис подчеркивает достижения однопартийца Барака Обамы, разработавшего закон о защите пациентов и доступном здравоохранении: Great news folks: we hit record-high health care enrollment. 31 million people now have coverage through the Affordable Care Act. Couldn't think of a better person to celebrate this milestone with than President Obama, so I gave him a call [Ibid.] (Отличные новости, ребята: мы достигли рекордно высокого уровня охвата населения медицинскими услугами. В настоящее время 31 миллион человек имеет доступ к медицинским услугам благодаря закону о доступной медицинской помощи. Я не мог найти лучшего человека, с которым можно было бы отпраздновать эту веху, чем президент Обама, поэтому я позвонил ему).

Анализ официального блога политика позволил получить схожие данные. Так, работая в администрации президента США, являясь правой рукой Джо Байдена, К. Харрис акцентирует внимание подписчиков на успешности проводимых правительством реформ, достижениях в области экономики, здравоохранения, образования и т. П. Данная тактика репрезентируется путем демонстрации статистических данных о количестве новых рабочих мест, людей, получивших вакцину, людей, получивших помощь и т. д. Например, для иллюстрации достижений в экономической сфере приводятся статистические данные, подчеркивающие результат работы администрации Джо Байдена: 850k jobs created in June [Vice President ...] (850 тыс. рабочих мест создано в июне).

В официальном блоге вице-президент говорит о достижениях не только в вопросе увеличения рабочих мест, но и в борьбе с пандемией, в масштабной кампании по вакцинированию населения страны: COVID-19 hospitalizations are down by more than $90 \%$ in the U.S. Getting vaccinated works [Ibid.] (Число госпитализаций сократилось более чем на 90 \%. Вакцинация работает).

В личном и официальном блогах контекстуально фиксируются:

1) фразы, содержащие слова с семантикой успеха и достижения: we hit record-high (мы достигли рекордно высокого уровня), we've gotten the pandemic under control (мы взяли пандемию под контроль), to celebrate this milestone (чтобы отпраздновать это важное событие), progress (прогресс);

2) лексемы, позволяющие положительно оценить достижения: great (отличный), better (лучше) и т. д.;

3) сравнительная и превосходная степени сравнения прилагательных: higher than ever before (выше, чем когда-либо прежде), available to more 
families than ever before (доступно большему количеству семей, чем когда-либо прежде), lowest unemployment rate (самый низкий уровень безработицы), fastest drop in long-term unemployment (самое быстрое снижение длительной безработицы).

В личном и официальном блогах данная тактика позволяет К. Харрис позиционировать себя членом успешной команды демократов, грамотным политиком, который под предводительством президента эффективно решает поставленные задачи.

\section{5. Тактика благодарности в личном и официальном блогах Камалы Харрис}

В личном блоге данная тактика позволяет К. Харрис позиционировать себя как благодарного человека и политика, который признателен за поддержку. Во-первых, было установлено, что в личном блоге вице-президента частотны сообщения с благодарностью от ее имени и от имени ее супруга. В основном благодарность выражалась всем тем, кто по долгу службы со всей ответственностью боролся с пандемией: @DouglasEmhoff and I called some of our frontline nurses like Liz to thank them for all they've done for our country [Kamala ...] (Дуглас Эмхофф и я звонили медсестрам, работающим, как и Лиз, на передовой, чтобы поблагодарить их за все, что они сделали для нашей страны).

Кроме того, в своем блоге К. Харрис благодарит всех мэров афроамериканцев, которые вносят вклад в борьбу с пандемией: Thank you to the Mayors of the African American Mayors Association, who are at the center of this pandemic response [Ibid.] (Спасибо мэрам Афроамериканской ассоциации мэров, которые находятся в центре этой борьбы с пандемией).

Слова благодарности политик адресовала и 38-му губернатору Калифорнии, актеру А. Шварценеггеру: Thank you Governor @Schwarzenegger for your powerful message to our country and for reminding us what's at stake in this moment [Ibid.] (Спасибо губернатору @Шварценеггеру за мощное послание нашей стране и за то, что напомнил нам, что поставлено на карту в данный момент).

В официальном блоге вице-президент США также предстает перед своими подписчиками человеком вежливым, не забывающим поблагодарить тех, кто работает с ней в одной команде на благо страны. Так, К. Харрис высказывает признательность своим коллегам за труд и результаты, достигнутые за стодневный период работы администрации президента: $W e$ hit 100 days in office this week. To mark the occasion, @SecondGentleman and I did a Zoom with the team. We thanked everyone for their hard work, dedication, and determination. So proud of what our team has accomplished on behalf 
of the American people. More to come! [Vice President ...] (На этой неделе 100 дней, как у власти. Чтобы отметить это событие, @Второй джентльмен и я провели совещание в Zoom с командой. Мы поблагодарили всех за их упорный труд, преданность делу и решимость. Так горжусь тем, что наша команда сделала для американского народа. Будет сделано еще больше!).

К. Харрис благодарит пожарных, волонтеров, женщин-демократов, многое сделавших для страны; штат Вермонт за принятие законопроекта, обеспечившего доступность голосования по почте; военнослужащих, пожертвовавших жизнями ради порядка в стране; членов Национальной гвардии штата Мэриленд, помогающим жителям Балтимора пройти вакцинацию; всех мам, бабушек, прабабушек, которые служат своим семьям, и др. Кроме того, в статусно-обусловленном дискурсе вице-президент выражает благодарность женщинам, которые помогали США во времена Второй мировой войны и поддерживают нацию в настоящем.

Анализ лексической репрезентации данной тактики в личном и официальном блогах позволил зафиксировать использование фраз со словами, имеющими семантику:

1) благодарности: to express our gratitude (выразить нашу благодарность), our nation's gratitude (благодарность от лица нашей нации), thank you for all the sacrifices (спасибо вам за все жертвы), thank you for all that you do (спасибо вам за все, что вы делаете), we are grateful for all that you are doing (мы благодарны за все, что вы делаете), I applaud Vermont (я аплодирую Вермонту), We owe these heroes everything (мы обязаны этим героям всем); при этом в контекстном окружении присутствуют эмоциональнооценочные слова и метафоры, выражающие положительную оценку тех, кого благодарят, например, these heroes (эти герои);

2) уважения: it was an honor (было честью), we honor the heroes (мы чтим героев) и т. п.

И в личном, и в официальном блогах, прибегая к тактике благодарности, К. Харрис презентует себя политиком, признательным за выказанное ей доверие, помнящим достижения предшественников, благодарным за службу, которую несут обычные граждане.

\section{6. Тактика отождествления}

\section{1. Мы американцы}

К. Харрис конструирует посредством сообщений в блогах чувство общности с целым рядом адресатов. Во-первых, это все граждане США, которым небезразлична судьба их страны, которые готовы бороться за свои права и способствовать росту благосостояния Америки: The right to vote is fundamental. It gives Americans a voice in what happens in our nation. When 
more people have a voice, our democracy becomes more representative, and our nation becomes stronger. We won't give up the fight to strengthen our right to vote [Kamala ...] (Право голоса имеет основополагающее значение. Это дает американцам право голоса относительно того, что происходит в нашей стране. Когда больше людей имеют право голоса, наша демократия становится более представительной, а наша нация становится сильнее. Мы не откажемся от борьбы за расширение права голоса).

Размещая на своей странице в официальном блоге публикацию президента, К. Харрис соглашается с его точкой зрения о том, что народ - это и есть страна. We are America. We don't just fix for today. We build for tomorrow [Vice President ...] (Мы - Америка. Мы не делаем ремонт на один день. Мы строим на будущее).

Вице-президент уверяет подписчиков в том, что, объединившись, американцы сделают демократию сильнее. When "We, the people" includes all the people, our democracy is stronger. We must continue to fight to protect Americans'fundamental right to vote [Ibid.] (Когда «мы, народ» включает в себя всех людей, наша демократия сильнее. Мы должны продолжать бороться за защиту фундаментального права американцев на голосование).

Тактика отождествления себя с американским народом актуализирована использованием лексем people, nation, America, Americans, the United States, we, our.

\section{2. Мы демократы}

Как представитель демократической партии, К. Харрис со своей личной страницы ратует за поддержку демократов и призывает спонсировать избирательные кампании демократов по всей стране. В записях, размещенных в блоге, лексема democrat и ее производные соседствуют с местоимениями we и our, словосочетаниями, включающими в себя лексемы с семантикой объединения - join us (присоединяйтесь к нам), и метафорами, выражающими положительную оценку представителям данной политической партии to build our country back (восстановить нашу страны).

\section{3. Мы - представители администрации президента}

К. Харрис на личной странице позиционирует себя политиком высшего эшелона власти, который заботится об улучшении жизни граждан страны: Far too many Americans still lack access to high-speed internet. Our Administration is working to get affordable, high-speed internet to every American household [Kamala ...] (Слишком многие американцы все еще не имеют доступа к высокоскоростному Интернету. Наша администрация работает над тем, чтобы обеспечить доступное и высокоскоростное подключение к Интернету в каждой американской семье). 
Дублируя сообщения с официальной страницы президента, позиционирующего свою команду «строителями» светлого будущего, К. Харрис переносит этот образ и на себя: In 2021, we're going to build a brighter future [Ibid.] (В 2021 году мы собираемся построить более светлое будущее).

В официальном блоге К. Харрис также подчеркивает, что она является неотъемлемой частью команды президента. Политик демонстрирует своим подписчикам совместную работу всех представителей правящей верхушки страны, направленную на решение самых актуальных вопросов: борьбу с коронавирусом, принятие Американского плана спасения, Американского плана занятости и Плана американских семей. At our first cabinet meeting, @POTUS and our team discussed implementing the American Rescue Plan, working to pass the American Jobs Plan, and continuing our fight against COVID. Working together, we have full confidence that we will deliver for the American people [Vice President ...] (На первом заседании кабинета @POTUS и наша команда обсудили реализацию Американского плана спасения, работу по принятию Американского плана занятости и продолжение нашей борьбы с COVID. Работая вместе, мы полностью уверены в том, что принесем пользу американскому народу).

Как показал анализ, личностно-обусловленный дискурс К. Харрис изобилует строительными метафорами, позволяющими не только позиционировать себя в созидательном ключе, но и имплицитно давать положительную оценку работе своей команды: build a brighter future for generations to come (построим светлое будущее для будущих поколений), to build an economy that's not only stronger but fairer for working people (построить экономику, которая будет не только сильнее, но и справедливее для работающих людей), will help to build a country that lifts up all Americans (помогут построить страну, в которой жизнь всех американцев станет лучше), we'll build that together (мы это построим вместе). В статусно-обусловленном дискурсе с целью осветить планомерную совместную работу представителей высшего уровня власти используются лексемы с семантикой:

- ‘производитель действия': we, cabinet, @POTUS, administration;

- 'деятельность': discuss, implement, work, pass, fight, deliver, support, help, take action;

— 'наш', 'вместе': our, together.

\section{4. Мы женщины-политики}

Важными составляющими имиджа К. Харрис являются ее гендер и раса. Одним из первых после выборов вице-президента был пост с признанием, что ее победа стала возможной только благодаря женщинам, которые проложили путь другим женщинам в политику: I'm here today because 
of the women who came before me [Kamala ...] (Я здесь сегодня благодаря женщинам, которые были до меня).

Достигнув небывалых высот на политическом олимпе США, Харрис - дочь этнической индианки и африканца - искренне радуется успехам женщин в политике в целом и успехам женщин, не являющихся представителями европеоидной расы. Truly a historic day with a record number of women - and women of color - being sworn in to Congress. Welcome! [Ibid.] (Поистине исторический день, когда рекордное число женщин, в том числе цветных женщин, были приведены к присяге в Конгрессе. Добро пожаловать!). В ее личном блоге зафиксированы поздравления с переизбранием на очередной политический пост, адресованные не только ее американским коллегам-женщинам, но и женщинам в африканских странах. Congratulations to fellow Californian, @SpeakerPelosi,for being reelected as Speaker of the House [Ibid.] (Поздравляю коллегу из Калифорнии Н. Пелоси с переизбранием на пост спикера палаты представителей США); Sending bestwishes to@SuluhuSamia following her swearing in as Tanzania’s new President — the first woman to hold the office [Ibid.] (Посылаю наилучшие пожелания Самии Сулуху после ее приведения к присяге в качестве нового президента Танзании - первой женщины, занявшей этот пост).

Частотны и сообщения К. Харрис о том, что во время экономического кризиса, вызванного пандемией, больше всего пострадали не белые женщины. Комментируя статью $\mathrm{CNN}$ о том, что во время пандемии женщины лишились работы, она указывает, что речь идет не о всех женщинах, а об афроамериканских и латиноамериканских женщинах. This disproportionately affects Black and Latina women who often lack paid sick leave or the ability to work from home [Ibid.] (Это непропорционально влияет на чернокожих и латиноамериканских женщин, которым часто не дают оплачиваемый отпуск по болезни или возможность работать на дому).

\section{5. Мы - женщины}

Если в личностно-обусловленном дискурсе К. Харрис делает основной акцент на том, что она входит в круг женщин-политиков, то в статусно-обусловленном дискурсе добавляется идентификация себя и с простыми женщинами США.

Согласно полученным данным, К. Харрис, являясь женщиной-политиком, презентует себя борцом за женские права, за право на труд и заботу о детях со стороны государства и пр.: We can't stop until every woman who wants a job has a good job. Because when we lift up women, we lift up our families, our communities, and our entire country is better off [Vice President ...] (Мы не можем остановиться, пока каждая женщина, которая хочет работать, не получит хорошую работу. Потому что, когда мы поднимаем 
женщин, мы поднимаем наши семьи, наши общины, и вся наша страна становится лучше).

На своей официальной странице К. Харрис также размещает публикации президента США, в которых он поддерживает ее как женщину вице-президента: Madam Speaker. Madam Vice President. No president has ever said those words from this podium — and it's about time [Ibid.] (Госпожа спикер. Госпожа вице-президент. Ни один президент не произносил эти слова с этой трибуны - настало время).

Американки охарактеризованы как обладающие стойкостью, силой, способностью преодолевать преграды, желанием работать, быть независимыми и защищенными. Женщины ассоциируются не только с семьей, но и с общиной, страной в целом. Перечисленные качества приписываются и самой К. Харрис. Данная тактика актуализирована лексемами we, our, lift up, family, community, country, cabinet, better, strong, powerful, workforce, work, break barriers.

\section{6. Мы - афроамериканцы}

Расовый вопрос занимает значимое место среди тем, привлекаемых К. Харрис для самопрезентации. В своем блоге, говоря о вкладе Джона Льюиса - американского конгрессмена, борца за права афроамериканцев, политик призывает афроамериканцев Джорджии принять участие в выборах в Сенат, напоминая о том, как нелегко было получено для них это право. The late great John Lewis shed his blood on the Edmund Pettus Bridge for our right to vote. The forces against him were powerful, but he knew the capacity of what our country could be was a fight worth having. Georgia, mask up today and march on to the ballot box in his honor [Kamala ...] (Покойный великий Джон Льюис пролил свою кровь на мосту Эдмунда Петтуса за наше право голоса. Силы, противостоявшие ему, были могущественны, но он знал возможности нашей страны и знал, что за это надо бороться. Джорджия, надень сегодня маску и маршируй к урне для голосования в его честь).

В сообщениях политика тема расы активно поднимается в связи с вопросами прав, свобод и благополучия не белых американцев. Контекстуальный анализ позволил установить, что лексемы black (чернокожий), people of color (небелые люди), race (paca) и the color of your skin (цвет кожи) чаще всего употребляются с такими словами, словосочетаниями и фразами, как injustice (несправедливость), racial injustice (расовая несправедливость), fight (борьба), struggle (вести борьбу), challenge (вызов), doesn't work equally for all (не работает одинаково для всех), disproportionately (непропорционально), pay disparity (неравенство в оплате труда), maternal mortality (материнская смертность). 
Без внимания не остаются культурные события, посвященные роли афроамериканцев в борьбе за равные права. К. Харрис пишет о месяце афроамериканской культуре (Black History Month), о Розе Паркс и других афроамериканцах, чьи действия повлияли на историю страны, изменив права и свободы афроамериканцев в США. We stand on the shoulders of those who came before. When Rosa Parks refused to give up her seat, she was lifting all of us up. Today, on her birthday, we honor her legacy and courage [Ibid.] (Мы опираемся на тех, кто был до нас. Когда Роза Паркс отказалась уступить свое место, она изменила к лучшему нашу с вами жизнь. Сегодня, в день ее рождения, мы чтим ее наследие и мужество).

В сообщениях официального блога К. Харрис упоминается имя афроамериканца Мартина Лютера Кинга - американского общественного деятеля, выступавшего за отмену законов о сегрегации. Несколько сообщений посвящено афроамериканцу Джорджу Флойду, гибель которого во время ареста в Миннеаполисе весной 2020 года вызвала массовые протесты по всей территории США. Темнокожие выступают против насилия со стороны полиции, призывают к борьбе за гражданские права афроамериканского населения США. We are all part of George Floyd's legacy. And now our job is to honor it - to honor him [Vice President ...] (Мы все являемся частью наследия Джорджа Флойда. И теперь наша задача - чтить его).

Анализ лексической составляющей подобных публикаций позволил зафиксировать употребление лексем we, our, all, honour, black, fight, racial, justice.

Таким образом, тактика отождествления позволяет политику репрезентировать себя темнокожей американкой, политиком высшего эшелона власти, членом Демократической партии.

\section{7. Гипертрофирование «я-темы»}

В случае с К. Харрис можно говорить о том, что даже в личностно-обусловленном дискурсе она минимально и очень аккуратно позиционирует «я-тему». В вопросах, касающихся ее работы вице-президентом, К. Харрис акцентирует свое «я», подчеркивая свою личную ответственность за решение поставленных вопросов восстановления экономики страны, иммиграции, задачи борьбы за равные права непривилегированных социальных групп и др.: so @JoeBiden and I can do the necessary work to help our nation heal and recover [Kamala ...] (для того, чтобы Джо Байден и я смогли сделать все необходимое, чтобы помочь нашей стране восстановиться). Анализ лексической репрезентации данной тактики, позволил зафиксировать использование: личного местоимения $I$ и те в сочетании с именем президента: @JoeBiden and I (Джо Байден и я), JoeBiden and mе (Джо Бай- 
ден и я); использование фамилии политика вместе с фамилией президента в наименованиях различных кампаний, проводимых ими, или планов по решению социально-экономических или политических проблем страны: The Biden-Harris COVID-19 response plan [Ibid.] (План борьбы БайденаХаррис с COVID-19).

Отметим, что «я-тема» в личностно-обусловленном дискурсе К. Харрис прослеживается и в небольшом количестве сообщений (в 8 из проанализированных 349), раскрывающих некоторые моменты ее биографии, особенности ее характера и информацию о ее семейной жизни.

Были зафиксированы сообщения о ее первом учителе - женщине, которая способствовала успеху К. Харрис в учебе, что помогло ей стать успешным юристом, а затем и политиком; сообщения о том, что ее мать, получившая докторскую степень по медицине, тоже всегда поддерживала ее, учила уважать любой труд и помнить о силе науки. На лексическом уровне местоимения $I$, my и nation были обнаружены в общем контексте как с лексемами, имеющими семантику 'успех', ‘достижения поставленных целей', ‘поддержка'», так и с лексемами, содержащими семы 'тяжелый труд', 'трудная задача', 'преодоление'. Это позволило политику подчеркнуть, что достичь подобных вершин ей помогло трудолюбие и поддержка учителей и матери: encourage (поощрять, подбадривать), inspire (вдохновлять), graduate from (завершить обучение), hard work (тяжелая работа), песеssary work (необходимая работа), confront (противостоять), challenges (вызовы, трудные задачи).

В нескольких сообщениях К. Харрис говорит теплые слова о детях своего мужа от первого брака, с которыми у нее прекрасные отношения, называя их our son и our daughter. Использование местоимений I, we, our в контексте с такими фразами, как we are so blessed (нам так повезло), our loved ones (наши близкие), congratulations (поздравления), proud of (гордиться), love (любить), позволяет политику показать важность для нее гармоничных семейных отношений.

Таким образом, тактика «Гипертрофирование “я-темы”» позволяет политику в профессиональной сфере подчеркнуть готовность брать ответственность на себя и принимать непосредственное участие в решении поставленных перед ней задач, а акцентирование своего «я» вне профессиональной сферы помогает продемонстрировать, что она такой же обычный человек, как и многие из тех, кто читает ее сообщения в социальной сети.

Анализ официальной страницы вице-президента США показал, что К. Харрис говорит о себе в контексте взятых на себя обещаний, выполненных обязательств, предстоящих действий. Она может ссылаться сама на себя, напоминая подписчикам о том или ином событии, выступлении, 
публикации. Так, политик делает отсылку к своим словам, произнесенным в день бракосочетания двух женщин: Крис Перри и Сэнди Стир, заключивших однополый брак в 2013 году в Калифорнии. As I said that day, through the ups and downs, the struggles and triumphs, Kris and Sandy were victorious. I believe the same is true - and will continue to be true - about the movement for equality [Vice President ...] (Как я сказала в тот день, несмотря на взлеты и падения, победы и поражения, Крис и Сэнди одержали победу. Я считаю, что это важно в отношении движения за равенство).

Как показал анализ, «я-тема» в статусно-обусловленном дискурсе К. Харрис прослеживается в сообщениях, показывающих ее как чуткого человека, способного сопереживать, и в сообщениях, касающихся ее семьи, ее родственников. От своего имени и от имени супруга Дугласа Эмхоффа (Douglas and I, Doug and I) К. Харрис адресует соболезнования родным и близким, погибшим во время обрушения здания Сарфсайд во Флориде; пострадавшим в трагедии на горе Мерон во время религиозного фестиваля Лаг ба-Омер; поздравляет христиан с праздником пасхи и всех, кто отмечает буддийский праздник Весак, и др. Упоминая вместе свое имя и имя своего супруга, К. Харрис презентует себя человеком семейным, для которого важны обычаи, она делится радостью и горем как с родными, так и с подписчиками.

В сообщениях о родных и близких К. Харрис зафиксированы лексемы с семантикой 'благодарность', 'гордость', ‘амбиции', ‘цель', 'вдохновлять', ‘поддерживать', 'ценить': I am forever grateful to her; I am so proud of you; keep dreaming with ambition; she had two goals in life; encouraged me; cheered me; to appreciate.

\section{8. Тактика обещания}

Сопоставительный анализ показал, что данная тактика используется политиком только в статусно-обусловленном дискурсе. Так, прибегая к тактике обещания, К. Харрис презентует себя человеком, заинтересованным в процветании своей страны, способным трудиться на ее благо, решая проблемы в области экономики, образования, здравоохранения, соблюдения прав социально незащищенных слоев населения и т. п. Своих подписчиков она заверяет в том, что принимаемые законопроекты направлены на улучшение жизни граждан страны. The Bipartisan Infrastructure Framework will: Create good union jobs. Strengthen our economy. Help our nation compete [Ibid.] (Двухпартийная инфраструктура создаст хорошие рабочие места для профсоюзов; укрепит нашу экономику; поможет нашей стране быть конкурентоспособной).

Продвигая Американский семейный план, вице-президент говорит об образовании, которое будет доступно каждому американцу: <..> The American Families Plan will give every American 2 years of free community 
college. And it will make college more affordable for millions of students [Ibid.] (<..> Американский семейный план предоставит каждому американцу 2 года бесплатного обучения в общественном колледже. Он сделает обучение в колледже доступным для миллионов студентов).

Тактика обещания представлена на грамматическом уровне глагольными формами простого будущего времени (will create, will strengthen, will help, will give, will make); на лексическом уровне - употреблением лексем со значением 'хороший', 'общедоступный', 'укрепить', 'создать' , 'помочь'.

\section{9. Выводы}

Гипотеза исследования в своей основной части подтвердилась. Так, анализ показал, что политический статус адресанта политического интернет-дискурса обусловливает то, что самопрезентация политика имеет незначительные расхождения в образах, которые создаются на личной и на официальной страницах в социальной сети. Как представляется, инвариантность образа политика в личностно- и статусно-обусловленном дискурсах может быть объяснена в первую очередь тем, что высказывания политического деятеля на любых информационных площадках, в дискурсе разных средств массовой коммуникации могут быть восприняты как официальное мнение правительства страны. Подобное положение вещей заставляет политика минимизировать личную составляющую даже в личностно-обусловленном дискурсе.

Все это объясняет определенные расхождения и с тем образом, который К. Харрис акцентирует в стартовой записи на ее личной странице в социальной сети Twitter. Политик позиционирует себя борцом, женой, Момалой, тетушкой, женщиной (Fighting for the people; wife; Momala; auntie; she / her). Анализ личностно-обусловленного дискурса выявил конструирование образа успешного юриста, политика, который активно борется за права и свободы эмигрантов, афроамериканцев и в первую очередь за права не белых женщин; она репрезентирует себя американкой и демократом. При этом личностный аспект минимизирован, о чем наглядно свидетельствуют цифры. Как упоминалось, лишь 8 из 349 сообщений раскрывают личностные аспекты жизни политика.

Такая же ситуация наблюдается и с тем образом, который К. Харрис обозначила на своей официальной странице, где политик позиционирует себя вице-президентом США, женой Второго Джентльмена, Момалой, тетушкой, борцом за права людей (Vice President of the United States; wife to the first @ SecondGentleman; Momala; auntie; fighting for the people). Статусно-обусловленный дискурс показывает К. Харрис успешным юристом, политиком высшего эшелона власти, который активно борется за права людей, гражданкой 
США и афроамериканкой. Личностный аспект также минимизирован, но все же присутствует, приближая политика к своим избирателям.

Дальнейший анализ стратегии самопрезентации политиков высшего эшелона власти в политическом интернет-дискурсе позволит выявить специфику визуального кодирования тактик самопрезентации.

\section{Источники}

1. Kamala Harris (@KamalaHarris) / Twitter. — Access mode : https://twitter.com/ kamalaharris (accessed 21.04.2021).

2. Vice President Kamala Harris (@VP) / Twitter. — Access mode : https://twitter.com/ $\mathrm{VP} /$ (accessed 21.04.2021).

\section{ЛИТЕРАТУРА}

1. Беседина E. A. Стратегия эвфемизации при формировании политического дискурса российского парламента в годы первой мировой войны / Е. А. Беседина, Т. В. Буркова, А. Н. Мичурин // Вопросы когнитивной лингвистики. - 2019. — № 2. - С. $75-$ 84. - DOI: 10.20916/1812-3228-2019-2-75-84.

2. Волошина C. B. Коммуникативная стратегия самопрезентации в автобио-графическом дискурсе / С. В. Волошина // Вестник Иркутского государственного технического университета. — 2014. - № 9 (92). — С. 261-265.

3. Горошко Е. И. Инстаграм как жанр 2.0 (на примере политической коммуникации) / Е. И. Горошко, Т. Л. Полякова // Жанры речи. - 2019. - № 4 (24). - С. 300 313. - DOI: 10.18500/2311-0740-2019-4-24-300-313.

4. Дайнеко П. М. Дискурсивные стратегии самопрезентации в институциональном интернет-общении : автореферат диссертации ... кандидата филологических наук : 10.02.19 / П. М. Дайнеко. - Москва, 2011. — 25 с.

5. Демешкина T. A. Коммуникативная стратегия самопрезентации в женском диалектном дискурсе (на материале автобиографических рассказов) / Т. А. Демешкина, М. А. Толстова // Текст. Книга. Книгоиздание. - 2020. — № 24. - С. 47-67. - DOI: $10.17223 / 23062061 / 24 / 3$.

6. Дмитриева A. B. Коммуникативные стратегии и тактики в видеотекстах французской политической рекламы / А. В. Дмитриева // Коммуникативные исследования. 2018. — № 3 (17). — C. 96-113. — DOI: 10.25513/2413-6182.2018.3.96-113.

7. Дубровская T. В. Стратегии положительно-оценочной репрезентации российскоитальянских отношений в российском внешнеполитическом дискурсе (на материале сайта МИД РФ) / Т. В. Дубровская // Научный диалог. — 2017. — № 10. - С. 26 - 40. DOI: $10.24224 / 2227-1295-2017-10-26-40$.

8. Карасик В. И. Языковой круг : личность, концепты, дискурс / В. И. Карасик. Волгоград : Перемена, 2002. — 477 с. — ISBN 5-88234-552-2.

9. Куралева Т. В. Самопрезентация в предвыборном дискурсе : корпусное исследование (на материале предвыборных речей Б. Сандерса и Х. Клинтон) / Т. В. Куралева, В. Н. Кондрашова // Научный диалог. - 2018. - № 4. - С. 100-112. - DOI: 10.24224/2227-1295-2018-4-100-112.

10. Милованова М. В. Русскоязычные политические блоги как актуальная практика протестной коммуникации : системно-коммуникативные измерения / М. В. Милова- 
нова, Е. В. Терентьева // Научный диалог. - 2020. - № 6. - С. 101-116. - DOI: 10.24224/2227 1295-2020-6-101-116.

11. Мишланов B. A. Коммуникативные стратегии и тактики в современном политическом дискурсе (на материале политической рекламы предвыборных кампаний 2003, 2007, 2008 гг.) / В. А. Мишланов, Н. С. Нецветаева // Вестник Пермского университета. Российская и зарубежная филология. - 2009. - Выпуск 6. - С. 5-13.

12. Моногарова А. Г. Речевое поведение британских политиков в обсуждении Брексита : прагматика, гендер и коммуникативное доминирование в политическом медиадискурсе / А. Г. Моногарова, Т. А. Ширяева, А. Ю. Багиян // Научный диалог. - 2020. № 10. - C. 114-127. — DOI: 10.24224/2227-1295-2020-10-114-127.

13. Мухортов Д. С. О прагмалингвистических особенностях вербального поведения американского президента Ричарда Никсона (на материале избранных речей) / Д. С. Мухортов // Вестник Российского университета дружбы народов. Серия : Теория языка. Семиотика. Семантика. - 2018. - Т. 9. - № 1. - С. 77-92. - DOI: 10.22363/2313-2299-2018-9-1-77-92.

14. Никифорова Э. Ш. Коммуникативные стратегии и тактики судебного дискурса / Э. Ш. Никифорова // Вестник Челябинского государственного университета. — 2012. № 17 (271). - C. $100-103$.

15. Орлова О. В. Проблема соотношения понятий стиля и дискурса в лингвистике начала XXI в. В контексте идей М. Н. Кожиной / О. В. Орлова // Вестник Томского государственного университета. Филология. — 2013. - № 4 (24). - С. 19-25. — DOI: $10.17223 / 19986645 / 24 / 2$.

16. Паршина O. Н. Стратегии и тактики речевого поведения современной политической элиты России : диссертация ... доктора филологических наук : 10.02.01/ О. Н. Паршина. - Саратов, 2005. - 325 с.

17. Суханов Ю. Ю. Политический дискурс как объект лингвистического анализа / Ю. Ю. Суханов // Вестник РУДН. Серия : Теория языка. Семиотика. Семантика. 2018. — № 9 (1). — C. 200-212. — DOI: 10.22363/2313-2299-2018-9-1-200-212.

18. Тымбай A. A. Коммуникативные стратегии американских политиков (на примере избирательной кампании 2016) / А. А. Тымбай // Вестник Российского университета дружбы народов. Серия : Теория языка. Семиотика. Семантика. — 2018. - Т. 9. № 1. - C. 105-123. — DOI: 10.22363/2313-2299-2018-9-1-105-123.

19. Уланов A. В. Коммуникативные стратегии в военном дискурсе / А. В. Уланов // Сибирский филологический журнал. - 2014. — № 4 (28). — С. 246 - 254.

20. Устинова О. В. Особенности репрезентации образа Канады в политическом дискурсе / О. В. Устинова // Вестник Российского университета дружбы народов. Серия : Теория языка. Семиотика. Семантика. — 2018. - Т. 9. — № 1. - С. 136-157. DOI: $10.22363 / 2313-2299-2018-9-1-136-157$.

21. Филаткина Г. С. Коммуникативные стратегии в политическом медиадискурсе президентов Венесуэлы, Эквадора, Бразилии (1999-2014 гг.) : диссертация ... кандидата филологических наук : 10.01.10 / Г. С. Филаткина. — Москва, 2015. - 265 с.

22. Чудинов А. П. Российская лингвополитическая персонология : исследование образов политических лидеров / А. П. Чудинов, Е. А. Нахимова, М. В. Никифорова // Вестник Российского университета дружбы народов. Серия : Теория языка. Семиотика. Семантика. - 2018. — Т. 9. — № 1. — C. 14-31. — DOI: 10.22363/2313-2299-2018-9-1-14-31.

23. Ширяев Н. С. Коммуникативные стратегии репрезентации национальной идентичности в политическом медиадискурсе (на материале английского и французского 
языков) : диссертация ... кандидата филологических наук : 10.02.19 / Н. С. Ширяев. Саратов, 2017. - C. 195.

24. Khajavi Y. A discourse analytic investigation into politician's use of rhetorical and persuasive strategies : The case of US election speeches / Y. Khajavi, A. Rasti // Cogent Arts \& Humanities. - 2020. — № 7 (1). — Pp. 1-15. — DOI: 10.1080/23311983.2020.1740051.

25. Sadeghi B. Towards (de-) legitimation discursive strategies in news coverage of Egyptian protest : VOA \& Fars news in focus / B. Sadeghi // Procedia-Social and Behavioral Sciences. — 2014. — № 98. - Pp. 1580-1589.

\section{MATERial RESOURCES}

Kamala Harris (@KamalaHarris). In: Twitter. Available at: https://twitter.com/kamalaharris. (accessed 21.04.2021).

Vice President Kamala Harris (@VP). In: Twitter. Available at: https://twitter.com/VP/ (accessed 21.04.2021).

\section{REFERENCES}

Besedina, E. A., Burkova, T. V., Michurin, A. N. (2019). Strategy of euphemization in the formation of the political discourse of the Russian parliament during the First World War. Questions of cognitive linguistics, 2: 75-84. DOI: 10.20916/1812-32282019-2-75-84. (In Russ.).

Chudinov, A. P., Nakhimova, E. A., Nikiforova, M. V. (2018). Russian linguopolitical personology: a study of images of political leaders. Bulletin of the People's Friendship University of Russia. Series: Theory of Language. Semiotics. Semantics, 9 (1): 14-31. DOI: 10.22363/2313-2299-2018-9-1-14-31. (In Russ.).

Daineko, P. M. (2011). Discursive strategies of self-presentation in institutional Internet communication. Author's abstract of PhD Diss. Moscow. 25 p. (In Russ.).

Demeshkina, T. A., Tolstova, M. A. (2020). Communicative strategy of self-presentation in women's dialect discourse (based on autobiographical stories). Text. Book. Book publishing, 24: 47-67. DOI: 10.17223/23062061/24/3. (In Russ.).

Dmitrieva, A. V. (2018). Communicative strategies and tactics in the video texts of French political advertising. Communicative research, 3 (17): 96-113. DOI: 10.25513/2413-6182.2018.3.96-113. (In Russ.).

Dubrovskaya, T. V. (2017). Strategies of Positive Representation of Russian-Italian Relations in Russian Foreign Policy Discourse (based on the Russian Foreign Ministry Website). Nauchnyi dialog, 10: 26 -40. DOI: 10.24224/2227-1295-2017-10-26-40. (In Russ.).

Filatkina, G. S. (2015). Communicative strategies in the political media discourse of the Presidents of Venezuela, Ecuador, Brazil (1999-2014). PhD Diss. Moscow. 265 p. (In Russ.).

Goroshko, E. I., Polyakova, T. L. (2019). Instagram as a genre 2.0 (on the example of political communication). Genres of speech, 4 (24): 300-313. DOI: 10.18500/23110740-2019-4-24-300-313. (In Russ.).

Karasik, V. I. (2002). Language circle: personality, concepts, discourse. Volgograd: Peremena. 477 p. ISBN 5-88234-552-2. (In Russ.).

Khajavi, Y., Rasti, A. (2020). A discourse analytic investigation into politician's use of rhetorical and persuasive strategies: The case of US election speeches. Cogent Arts \& Humanities, 7 (1): 1—15. DOI: 10.1080/23311983.2020.1740051. 
Kuraleva, T. V., Kondrashova, V. N. (2018). Self-Presentation in Campaign Discourse: CorpusAssisted Study (A Case of B. Sanders's and H. Clinton's Campaign Speeches). Nauchnyi dialog, 4: 100 - 112. DOI: 10.24224/2227-1295-2018-4-100-112. (In Russ.).

Milovanova, M. V., Terentyeva, E. V. (2020). Russian Political Blogs as Relevant Practice of Protest Communication: Systemic-Communicative Dimensions. Nauchnyi dialog, 6: 101-116. DOI: 10.24224/2227-1295-2020-6-101-116. (In Russ.).

Mishlanov, V. A., Netsvetaeva, N. S. (2009). Communicative strategies and tactics in modern political discourse (based on the material of political advertising of election campaigns in 2003, 2007, 2008). Bulletin of Perm University. Russian and foreign philology, 6: 5-13. (In Russ.).

Monogarova, A. G., Shiryaeva, T. A., Bagiyan, A. Yu. (2020). Speech Behavior of British Politicians in Discussion of Brexit: Pragmatics, Gender and Communicative Dominance in Political Media Discourse. Nauchnyi dialog, 10: 114-127. DOI: 10.24224/2227-1295-2020-10-114-127. (In Russ.).

Mukhortov, D. S. (2018). On the pragmalinguistic features of the verbal behavior of American President Richard Nixon (based on selected speeches). Bulletin of the People's Friendship University of Russia. Series: Theory of Language. Semiotics. Semantics, 9 (1): 77-92. DOI: 10.22363/2313-2299-2018-9-1-77-92. (In Russ.).

Nikiforova, E. S. (2012). Communicative strategies and tactics of judicial discourse. Bulletin of Chelyabinsk State University, 17 (271): 100-103. (In Russ.).

Orlova, O. V. (2013). The problem of the correlation of the concepts of style and discourse in linguistics of the beginning of the XXI century. In the context of M. N. Kozhina's ideas. Bulletin of Tomsk State University. Philology, 4 (24): 19-25. DOI: 10.17223/19986645/24/2. (In Russ.).

Parshina, O. N. (2005). Strategies and tactics of speech behavior of the modern political elite of Russia. Doct. Diss. Saratov. 325 p. (In Russ.).

Sadeghi, B. (2014). Towards (de-) legitimation discursive strategies in news coverage of Egyptian protest: VOA \& Fars news in focus. Procedia-Social and Behavioral Sciences, 98: 1580-1589.

Shiryaev, N. S. (2017). Communicative strategies of representation of national identity in political media discourse (based on the material of English and French). $\mathrm{PhD}$ Diss. Saratov. 195 p. (In Russ.).

Sukhanov, Yu. Yu. (2018). Political discourse as an object of linguistic analysis. Bulletin of the RUDN. Series: Theory of Language. Semiotics. Semantics, 9 (1): 200 212. DOI: 10.22363/2313-2299-2018-9-1-200-212. (In Russ.).

Tymbai, A. A. (2018). Communicative strategies of American politicians (on the example of the 2016 election campaign). Bulletin of the People's Friendship University of Russia. Series: Theory of Language. Semiotics. Semantics, 9 (1): 105-123. DOI: 10.22363/2313-2299-2018-9-1-105-123. (In Russ.).

Ulanov, A. V. (2014). Communicative strategies in military discourse. Siberian Philological Journal, 4 (28): 246-254. (In Russ.).

Ustinova, O. V. (2018). Features of the representation of the image of Canada in political discourse. Bulletin of the People's Friendship University of Russia. Series: Theory of Language. Semiotics. Semantics, 9 (1): 136 - 157. DOI: 10.22363/2313-22992018-9-1-136-157. (In Russ.).

Voloshina, S. V. (2014). Communicative strategy of self-presentation in autobiographical discourse. Bulletin of Irkutsk State Technical University, 9 (92): 261-265. (In Russ.). 